\title{
Antibodies to cardiolipin in patients with primary biliary cirrhosis
}

\author{
John Verrier Jones, BM, FRCP, FRCPC, DIANNe P. MOSHER, MD, FRCPC, EDITH JONES, BM, MRCP, FRCPC, \\ C. Noel Williams, MD, FRCPC, FACP, Dickran Malatjalian, MD, FCAP, RONAld I. CARR, MD, PhD, \\ Mervat Mansour, PHD
}

\begin{abstract}
Antibodies to cardiolipin have been recognized in up to $65 \%$ of patients with systemic lupus erythematosus. It has been claimed that they are significantly associated with intravascular thrombosis and with obstetrical complications. Thus far they have been found to be less prevalent in other diseases. Because of the high concentration of cardiolipin in mitochondrial membranes and the presence of antimitochondrial antibodies in patients with primary biliary cirrhosis, the authors investigated the prevalence of antibodies to cardiolipin in a group of 31 patients with primary biliary cirrhosis. It was found that the prevalence and levels of anticardiolipin antibodies of $\operatorname{lgG}$ and $\lg A$ isotype are as high in patients with primary biliary cirrhosis as in 35 consecutive patients with systemic lupus erythematosus. None of the patients with primary biliary cirrhosis gave any history of venous or arterial thrombosis. The rate of miscarriage was less than that reported for the general population. The availability for study of a second group of patients with high levels of anticardiolipin antibodies should make it possible to determine whether the association of these antibodies with thrombosis and fetal wastage in patients with systemic lupus erythematosus is a direct relationship or an epiphenomenon. Can J Gastroenterol 1989;3(3):98-102. Pour resumé voir page 99
\end{abstract}

Key Words: Anticardiolipin antibodies, Antimitochondrial antibodies, Primary biliary cirrhosis, Systemic lupus erythematosus

Departments of Medicine and Pathology, Dalhousie University; and the Victoria General Hospital, Halifax, Nova Scotia

Correspondence and reprints: Dr John Verrier Jones, Head, Division of Rheumatology,

Halifax Civic Hospital, 5938 University Avenue, Halifax, Nova Scotia B3H IV9

This work was presented in part at the American Rheumatism Association meeting

in Washington, DC in June, 1987

Received for publication August 5, 1988. Accepted March 23, 1989
A NTIBODIES TO PHOSPHOLIPID ANTIgens have been recognized since 1942 when Pangborn (1) described the isolation from beef heart of cardiolipin (diphosphatidyl glycerol) and showed that it was the antigen active in the Wasserman reaction for syphilis. Anticardiolipin antibodies are frequently found in association with the circulating 'anticoagulant' in patients with systemic lupus erythematosus (SLE)(2) which leads to a prolongation of the partial thromboplastin time and which is an immunoglobulin interfering with phospholipid dependent coagulation tests (3).

A great deal of attention has recently been focused on anticardiolipin antibodies in SLE. It has been claimed that they are associated with a significantly increased risk of arterial and venous thrombosis $(4,5)$. During pregnancy they appear to be predictors of fetal distress or death (6). Estimates of the frequency of lupus anticoagulant in patients with SLE have varied between 6 and $65 \%$. Harris and colleagues (7) found anticardiolipin antibodies in $62 \%$ of patients with SLE, 


\section{Anticorps dirigés contre la cardiolipine chez les patients atteints de cirrhose biliaire primitive}

RESUME: Les anticorps contre la cardiolipine ont été identifiés chez $65 \%$ des patients souffrant de lupus érythémateux aigu disséminé. On a soutenu qu'ils étaient associés de façon significative à la thrombose intravasculaire et aux complications obstétricales. Jusqu'à présent, on semble les trouver moins fréquemment dans d'autres maladies. A cause de la forte concentration de cardiolipine dans les membranes mitochondriales, et de la présence d'anticorps anti-mitochondriaux chez les patients atteints de cirrhose biliaire primitive, nous avons étudié la prévalence d'anticorps anti-cardiolipine chez un groupe de 31 patients souffrant de cette affection. D'après les résultats, la prévalence et les niveaux d'anticorps anti-cardiolipine d'isotypie $\operatorname{IgG}$ et $\operatorname{Ig} A$ sont aussi élevés chez les patients atteints de cirrhose biliaire primitive que chez 35 patients consécutifs souffrant de lupus érythémateux aigu disséminé. Aucun des patients atteints de cirrhose biliaire primitive ne présentait une histoire de thrombose veineuse ou artérielle. Chez les patientes, le taux d'avortement était inférieur à celui de la population générale. Avoir accès, pour fin d'étude, à un second groupe présentant des concentrations élevées d'anticorps anti-cardiolipine permettrait de déterminer si l'association de ces anticorps aux thromboses, et à la résorption du foetus chez les patientes atteintes de lupus érythémateux aigu disséminé, constitue une relation directe ou un épiphénomène.

while Sturfelt et al (8) reported their presence in $54 \%$ of 59 unselected SLE patients. However, in a recent study (9) of 60 consecutive patients lupus anticoagulant was found in $6.7 \%$ and anticardiolipin antibodies in $25 \%$.

Recent studies have shown that lupus anticoagulant and anticardiolipin antibodies may be found in diseases other than SLE. Lupus anticoagulant has been found in $4 \%$ of young adults with cerebrovascular disease (10) and in $27 \%$ of patients with syphilis (11). It has also been reported in $37 \%$ of psychiatric patients treated with phenothiazines (12), in whom it is presumably drug induced. Hull and co-workers (13) recently reported a study of anticardiolipin antibodies in 70 patients with Behcet's syndrome and detected the antibodies in 13 , of whom eight had a history of vascular pathology. Anticardiolipin antibodies have also been reported in single cases of Degos' disease (14) and Guillain-Barré syndrome (15). Recently, Canoso et al (16) reported anticardiolipin antibodies in all of 43 patients with acquired immune deficiency syndrome (AIDS) or AIDS-related complex as well as five of 10 men positive for antibodies to human immunodeficiency virus (HIV). None of these patients had a history of venous or arterial thrombosis.

Because of the high levels of cardiolipin in mitochondrial membranes and the high frequency of antimitochondrial iary cirrhosis, the authors decided to study the prevalence and concentration of anticardiolipin antibodies in patients with this condition.

The purpose of this paper is to report the detection of high levels of antibodies to cardiolipin in patients with primary biliary cirrhosis. The authors found that the prevalence of these antibodies, their isotype and their level in serum was comparable to that found in a group of 35 unselected patients with SLE. An increased incidence of venous or arterial thrombosis or of fetal wastage among the primary biliary cirrhosis patients was not found.

\section{PATIENTS AND METHODS}

Thirty-one sera from the files of the immunopathology laboratory at the Victoria General Hospital, Halifax, Nova Scotia, were studied. All were positive for antimitochondrial antibody at a dilution of 1:100 or greater and all patients had a diagnosis of definite or probable primary biliary cirrhosis. Twenty patients were symptomatic and 11 were asymptomatic. In 21 patients the diagnosis was confirmed by liver biopsy. In the remaining 10 liver biopsy was either refused (two patients), nondiagnostic (one patient) or not performed because of elevated prothrombin and partial thromboplastin antibodies in patients with primary bil- times due to end stage liver failure (seven patients). All 10 patients were diagnosed as having primary biliary cirrhosis based on their clinical course and persistent elevation of alkaline phosphatase and gammaglutamyl transferase. For comparison, the sera of 35 consecutive patients (mean age $\pm \mathrm{SD} 41.9 \pm 11.95$ years) attending the lupus clinic and 35 control specimens from normal staff (mean age $35.4 \pm 12$ years) of the hematology laboratory at the Victoria General Hospital were examined (all ages are given at the time serum was taken). All lupus patients fulfilled three or more of the American Rheumatism Association revised criteria for the diagnosis of SLE (17).

The mean age of the patients with primary biliary cirrhosis was $59.6 \pm 11.3$ years. There were 26 females and five males with primary biliary cirrhosis, and 32 females and three males in the lupus group. The patients with primary biliary cirrhosis were interviewed by telephone The female patients were questioned as to the number of pregnancies, miscarriages and stillbirths. All patients were asked a series of questions designed to elicit a history of vascular thrombosis or embolism. Specifically, each patient was asked whether he or she had ever suffered an episode of venous or arterial occlusion requiring medical or surgical treatment. All of the patients' charts were also reviewed to confirm the results of the telephone interview. None of the patients was receiving phenothiazines at the time that blood was taken. None was suffering from syphilis or HIV infection.

Antibodies to cardiolipin: All sera were frozen immediately after being taken and stored in aliquots at $-70^{\circ} \mathrm{C}$. Each sample tested was thawed once only before measurement of antibody. Anticardiolipin antibodies were measured by an amplified ELISA assay as described by Carr et al (18). In brief, Linbro 96 well microtitre plates were coated with 45 $\mu \mathrm{g} / \mathrm{mL}$ cardiolipin (Sigma C 1649) in $95 \%$ ethanol. The solution was evaporated under a stream of nitrogen and the plates postcoated with $3 \mathrm{mg} / \mathrm{mL}$ gelatin in phosphate buffered saline (PBS) for $2 \mathrm{~h}$ at room temperature. After washing the plates with PBS, test sera diluted $1 / 100$ in gelatin/PBS were added to the wells and incubated for 90 mins at room 


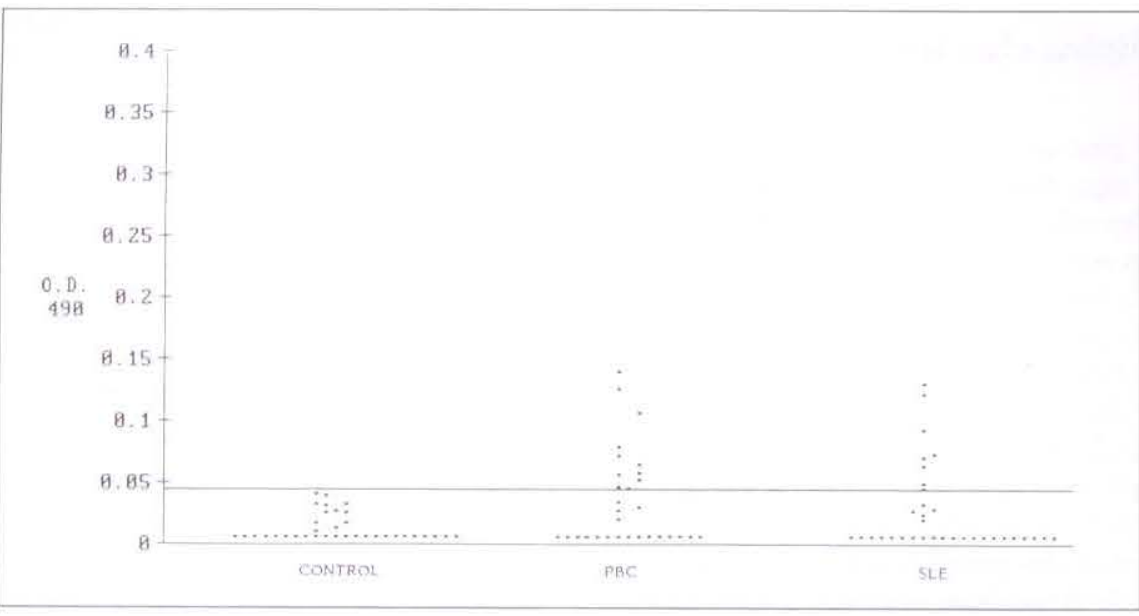

Figure 1) IgG anticardiolipin as measured by optical density ( $490 \mathrm{~nm}$ ) in controls and patients with primary biliary cirrhosis or SLE. The horizontal line represents the mean plus three standard deviations for the normal controls

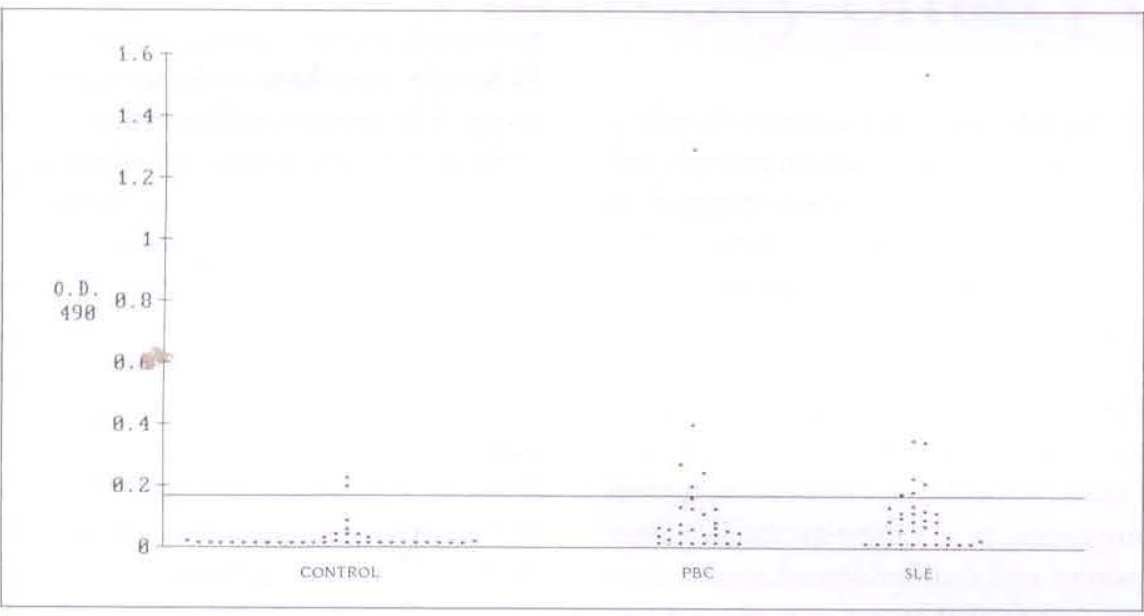

Figure 2) IgM anticardiolipin as measured by optical density ( $490 \mathrm{~nm}$ ) in controls and patients with primary biliary cirrhosis or SLE. The horizontal line represents the mean plus three standard deviations for the normal controls

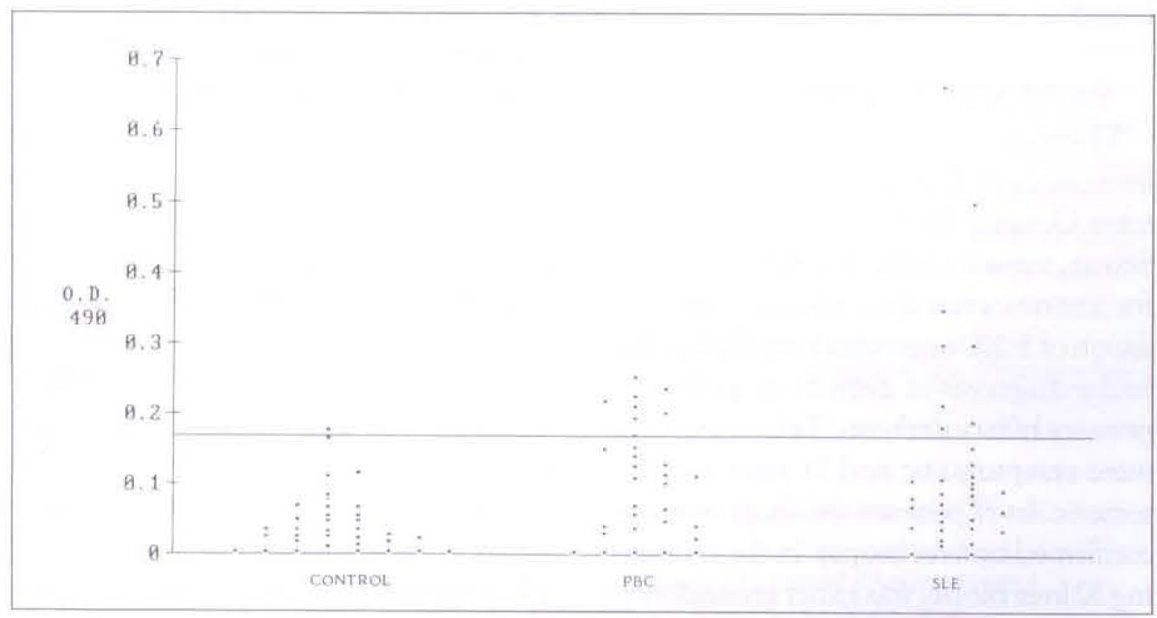

Figure 3) $\lg$ A anticardiolipin as measured by optical density $(490 \mathrm{~nm})$ in controls and patients with primary biliary cirrhosis or SLE. The horizontal line represents the mean plus three standard deviations for the normal controls temperature. Plates were washed, and alkaline phosphatase-conjugated heavy chain specific antisera to human IgG, IgM or IgA (Sigma, St Louis, Missouri) were added. The plates were then incubated for $1 \mathrm{~h}$ at room temperature. After washing, the primary and secondary substrate of the amplified system were added. Absorbance was read after 10 mins at $490 \mathrm{~nm}$ on an automated EL 310 ELISA reader (Biotek, Cambridge, Massachussetts). Sera were regarded as positive if the test gave an optical density value of more than three standard deviations above the mean for normals. Uncoated wells were used as controls to detect nonspecific binding, this was then subtracted from the optical density value.

Antimitochondrial antibodies: Antimitochondrial antibodies were assayed by an indirect immunofluorescence method using cryostat sections of mouse kidney for screening and subsequently using human kidney for titration. Bound antibodies were identified using FITC labelled antihuman immunoglobulin.

Statistical analysis: Fisher's exact test (two-tailed) was applied to compare the number of positives in each group.

\section{RESULTS}

Figures 1, 2 and 3 show the levels of anticardiolipin antibodies of each isotype detected in the three sets of sera.

For all isotypes of antibody, the levels of anticardiolipin were as high in the primary biliary cirrhosis group as they are in the SLE group. Table 1 shows the analysis of antibody isotype in each of the groups studied. For anticardiolipin antibody of $\operatorname{IgG}$ and $\operatorname{Ig} \mathrm{A}$ isotype in the primary biliary cirrhosisgroup, the number of positive patients was significantly higher than normals but not statistically different from the SLE group.

When the 31 patients with primary biliary cirrhosis were divided into the 21 in whom the diagnosis was confirmed by liver biopsy and the 10 in whom the diagnosis was established clinically, it was found that six of the former group and four of the latter group were positive for IgG antibodies to cardiolipin.

There was no correlation between antibodies to double stranded and single stranded DNA and the presence of anticardiolipin antibody in the primary bil- 
TABLE 1

Isotypes of anticardiolipin antibody: Number of patients with optical density greater than three standard deviations above the normal mean

\begin{tabular}{lccc}
\hline Immunoglobulin isotypes & Normal & SLE & PBC \\
\hline $\lg G$ & 0 & 7 & 10 \\
$\lg M$ & 2 & $P=0.014$ & $P=0.001$ \\
$\lg A$ & 1 & 5 & 6 \\
Total & & $P=0.26$ & $P=0.26$ \\
\hline
\end{tabular}

PBC Primary biliary cirrhosis; "Pvalues against normal controls

TABLE 2

Outcome of pregnancy in primary biliary cirrhosis patients

\begin{tabular}{lcccc}
\hline & $\begin{array}{c}\text { Number of } \\
\text { female patients }\end{array}$ & $\begin{array}{c}\text { Total number of } \\
\text { pregnancies }\end{array}$ & $\begin{array}{c}\text { Number of patients } \\
\text { with spontaneous } \\
\text { abortions }\end{array}$ & $\begin{array}{c}\text { Number of } \\
\text { spontaneous } \\
\text { abortions }\end{array}$ \\
\hline $\begin{array}{c}\text { Anticardiolipin } \\
\text { antibody positive }\end{array}$ & 7 & 19 & 1 & 1 \\
$\begin{array}{c}\text { Anticardiolipin } \\
\text { antibody negative }\end{array}$ & 13 & 41 & 4 & 5 \\
\begin{tabular}{c} 
Total \\
\hline
\end{tabular} & 20 & 60 & 5 & 6 \\
\hline
\end{tabular}

iary cirrhosis group (data not shown). Of the patients with SLE, four were positive for antimitochondrial antibodies. Two of these were also positive for anticardiolipin, while two were negative.

ivunoz et al (19) have suggested that in patients with primary biliary cirrhosis, IgM may bind nonspecifically in the ELISA assay for anticardiolipin antibodies. In the group of patients with primary biliary cirrhosis three of 16 showed high nonspecific binding for IgM and have been categorized as antibody negative. There was no nonspecific binding with the SLE group.

Of the 31 primary biliary cirrhosis patients, 23 were reached by telephone. None of these patients gave a history of venous or arterial thrombosis. Of the eight patients (two male, six female) not contacted, three had died of end stage liver failure and five were alive but lost to follow-up. Of a total of six females dead or lost to follow-up, three were positive for anticardiolipin antibodies while three were negative.

The charts of all patients lost to followup were reviewed. Of the six females lost to follow-up, obstetrical histories were missing from all but one chart. This patient had eight normal deliveries and no abortions. One 73-year-old male was found to have had a bypass graft of the left femoral artery for occlusion after a history of intermittent claudication. This patient was negative for anticardiolipin antibodies.

Twenty-one of the 23 patients interviewed by telephone were female. Among the seven patients with primary biliary cirrhosis who were anticardiolipin antibody positive there were 19 pregnancies with only one abortion. In the 13 anticardiolipin antibody negative patients, three had one spontaneous abortion while one patient had two. There was no case of fetal loss after 20 weeks. Thus, in the primary biliary cirrhosis group, anticardiolipin antibodies were not associated with an increased risk of fetal loss.

\section{DISCUSSION}

There has been a major upsurge of interest in the antiphospholipid antibodies since the demonstration that they may be predictors of intravascular thrombosis (5) and obstetrical complications (6). The mechanism by which these adverse effects are produced is still obscure. Suggested mechanisms include blocking the release of arachidonic acid from the membrane of the endothelial cells by binding to phospholipids (20) and decrease in the release of plasminogen activator following venous occlusion (21).

The mechanism of the obstetrical complications is also uncertain, although it has been reported that the lupus anticoagulant may affect the placental circulation by inhibiting the production of prostacyclin by the myometrium (22). Studies of the pathology of placental tissue associated with fetal loss in patients with SLE have shown that the placentae are small, often with multiple infarcts secondary to thrombosis (23).

In relation to both the thrombotic and the obstetric complications associated with antiphospholipid antibodies it is still uncertain "whether antiphospholipids play a pathogenic role... or are merely "markers' for ... disease" (4). SLE is characterized by the production of large numbers of autoantibodies and by excessive B-cell proliferation (24). While antiphospholipid antibodies appear to be risk factors for vascular and obstetric complications, some of the many other immunologic abnormalities found in SLE could be equally important.

The authors have shown that antibodies to cardiolipin occur as frequently in a group of patients with primary biliary cirrhosis as in SLE and that the level of antibody is similar in both groups. The authors have found no increase in the frequency of venous or arterial thrombosis. The authors found no increase in fetal wastage in the anticardiolipin positive patients, compared to those who were anticardiolipin negative, although it was recognized that the higher mean age of the primary biliary cirrhosis group makes this observation of questionable significance. It has been shown that the prevalence of anticardiolipin antibodies of $\operatorname{IgG}$ isotype increases in an ageing population (mean age 81 ) (25). However, the present patients with primary biliary cirrhosis, although somewhat older than the SLE group (mean age 59.6 years), showed anticardiolipin antibodies in all three immunoglobulin isotypes.

While it seems probable that the presence of anticardiolipin antibodies is a predictor for thrombosis and fetal wastage in some patients with SLE, and perhaps in some individuals with no other identifiable disease, the present study indicates that patients with primary biliary cirrhosis may have an equally high incidence and concentration of anticardiolipin antibodies without sustaining any of these complications. 
ACKNOWLEDGEMENTS: This work was supported by the Arthritis Society and the Lupus Foundation of America.

\section{REFERENCES}

1. Pangborn MC. A new serologically active phospholipid from beef heart. Proc Soc Exp Biol 1942;48:484-6.

2. Byron MA. The clotting defect in SLE. Clin Rheum Dis 1982;8:137-51.

3. Blatt PM, Martin E. The lupus anticoagulant. Arch Pathol Lab Med 1987;111:113-4.

4. Hughes GRV, Harris EN, Gharavi AE. Antiphospholipid antibodies. In: Gupta S, Talal N, eds. Immunology of Rheumatic Diseases. New York: Plenum Medical Book Co, 1985:251-69.

5. Hughes GRV. The anticardiolipin syndrome. Clin Exp Rheumatol 1985; 3:285-6

6. Lockshin MD, Druzin ML, Goei S, et al. Antibody to cardiolipin as a predictor of fetal distress or death in pregnant patients with systemic lupus erythematosus. N Engl] Med 1985;313:152-6.

7. Harris EN, Gharavi AE, Boey ML, et al. Anticardiolipin antibodies: Detection by radioimmunoassay and association with thrombosis in systemic lupus erythematosus. Lancet 1983; ii: 1211 .

8. Sturfelt G, Nived O, Norberg R, Thorstensson R, Krook K. Anticardiolipin antibodies in patients with systemic lupus erythematosus. Arthritis Rheum 1987;30:382-8.

9. Petri M, Rheinschmidt M, WhitingO'Keefe Q, Hellman D, Corash L. The frequency of lupus anticoagulant in systemic lupus erythematosus. A study of 60 consecutive patients by activated partial thromboplastin time, Russell viper venom test and anticardiolipin antibody level. Ann Intern Med 1987; 106:524-31.

10. Hart RG, Miller VT, Coull BM, Bril V. Cerebral infarction associated with lupus anticoagulants. Preliminary report. Stroke 1984;15:114-8.

11. Guillaume JC, Gouault-Heilman M, Dumont MD, Touraine R. Inhibiteur acquis de la coagulation de type antiprothombinase et syphilis récent. Ann Dermatol Venereol 1981; 108:139-43

12. Canoso RT, Sise HS. Chlorpromazineinduced lupus anticoagulant and associated immunologic abnormalities. Am J Hematol 1982;13:121-9.

13. Hull RG, Harris EN, Gharavi AE, et al. Anticardiolipin antibodies: Occurrence in Behcet's syndrome. Ann Rheum Dis 1984:43:746-8

14. Englert H, Boey ML, Derue G, Hull RG, Harris EN, Hughes GRV. Degos' disease: Association with anticardiolipin antibodies and the lupus anticoagulant. Br Med J 1984;289:576.

15. Harris EN, Englert H, Derue G, Gharavi AE, Hughes GRV. Antiphospholipid antibodies in acute Guillain-Barre syndrome. Lancet 1983;i:1361.

16. Canoso RT, Zon LI, Groopman JE. Anticardiolipin antibodies associated with HTLV-III infection. $\mathrm{Br} J$ Hematol 1987;65:495-8.

17. Tan EM, Cohen AS, Fries JF, et al. The 1982 revised criteria for the classification of systemic lupus erythematosus (SLE). Arthritis Rheum 1982;25:1271-7.

18. Carr RI, Mansour MF, Sadi D, James H, Jones JV. A substrate amplification system for enzyme-linked immunoassays: Demonstration of its general applicability to ELISA systems for detecting antibodies and immune complexes. J Immunol Methods 1987; 98:201-8. (Erratum 1987:103;157).

19. Munoz S, Cowchock S, Ruch D. Norberg R, Maddrey W. Anticardiolipin antibodies in primary biliary cirrhosis. Gastroenterology 1987:92:1758.

20. Carreras LO, Vermelyn JG. "Lupus' anticoagulant and thrombosis - A possible role of inhibition of prostacyclin formation. Thromb Haemost 1982; 48:38-40.

21. Angeles-Cano E, Sultan Y, Clauvel JP. Predisposing factors to thrombosis in systemic lupus erythematosus: Possible relation to endothelial cell damage. J Lab Clin Med 1979;94:315-23.

22. Carreras LO, Defreyn G, Machin SJ Arterial thrombosis, intrauterine death and lupus anticoagulant: Detection of immunoglobulin interfering with prostacyclin formation. Lancet 1981;i:244-6.

23. Hanly JG, Gladman D, Ros R, Laskin CA, Urowiz MB. Lupus pregnancy: A prospective study of placental changes. Arthritis Rheum 1987;31:358-66.

24. Glinski W, Gershwin ME, Budman DR, Steinberg AD. Study of lymphocyte subpopulations in normal humans and patients with systemic lupus erythematosus by fractionation of peripheral blood lymphocytes on a discontinuous Ficoll gradient. Clin Exp Immunol 1976; 26:228-38

25. Manoussakis MN, Tzioufas AG, Silis MP, Pange PJE, Goudevenos ], Moutsopoulos HM. High prevalence of anticardiolipin and other antibodies in a healthy elderly population. Clin Exp Immunol 1987;69:557-565. 


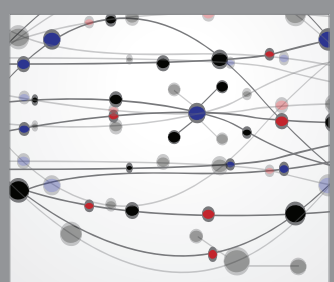

The Scientific World Journal
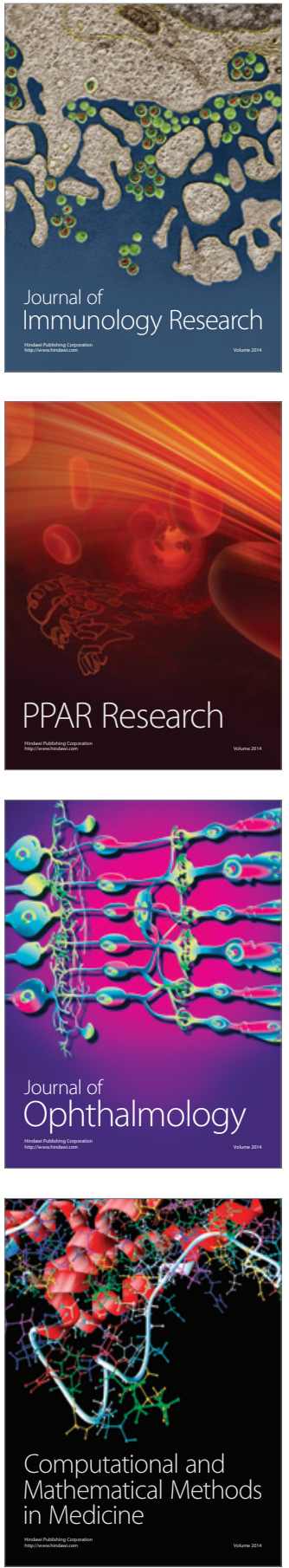

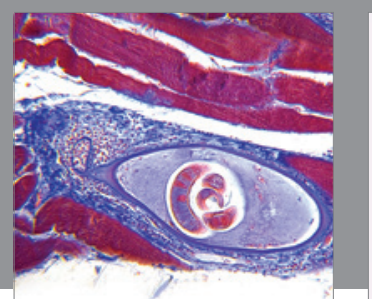

Gastroenterology Research and Practice

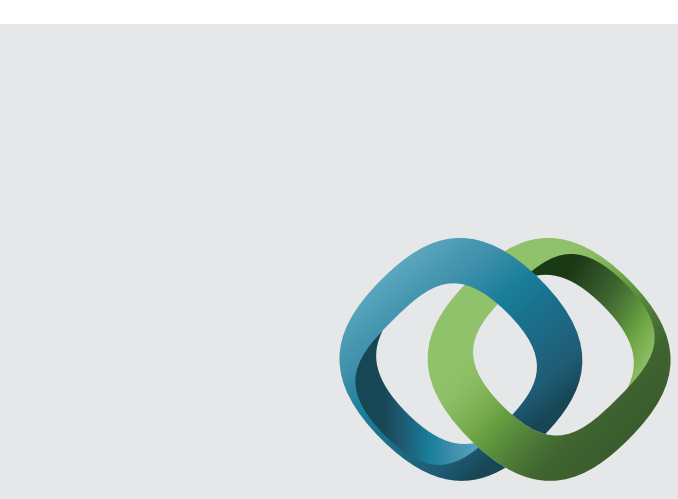

\section{Hindawi}

Submit your manuscripts at

http://www.hindawi.com
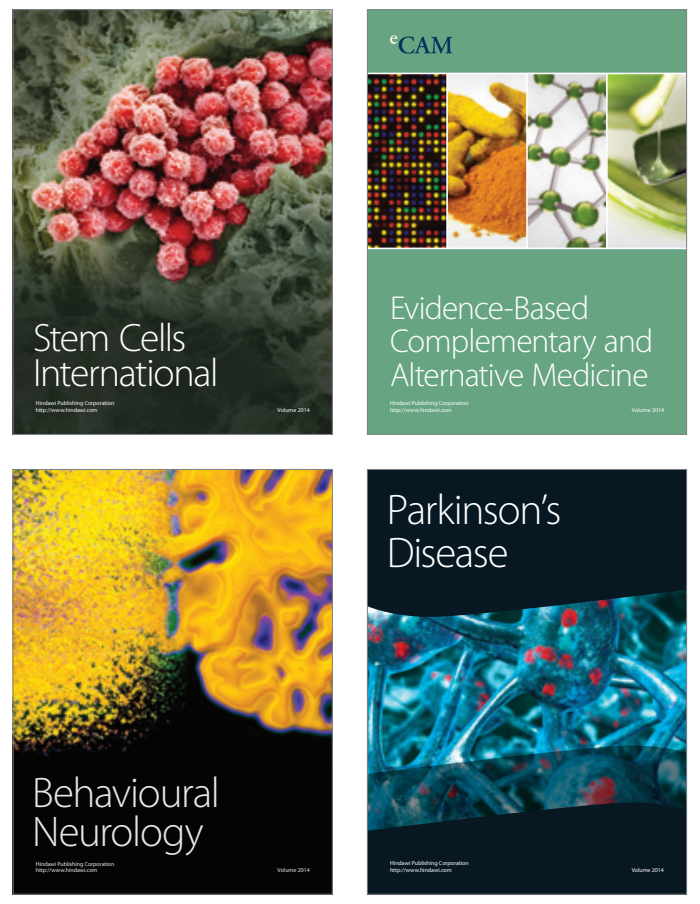
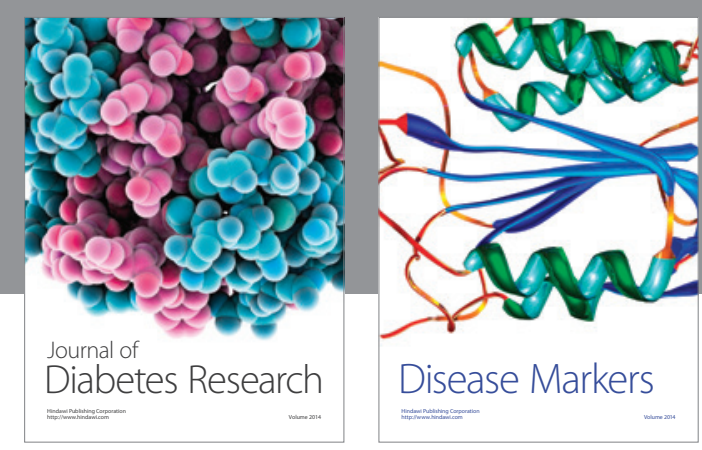

Disease Markers
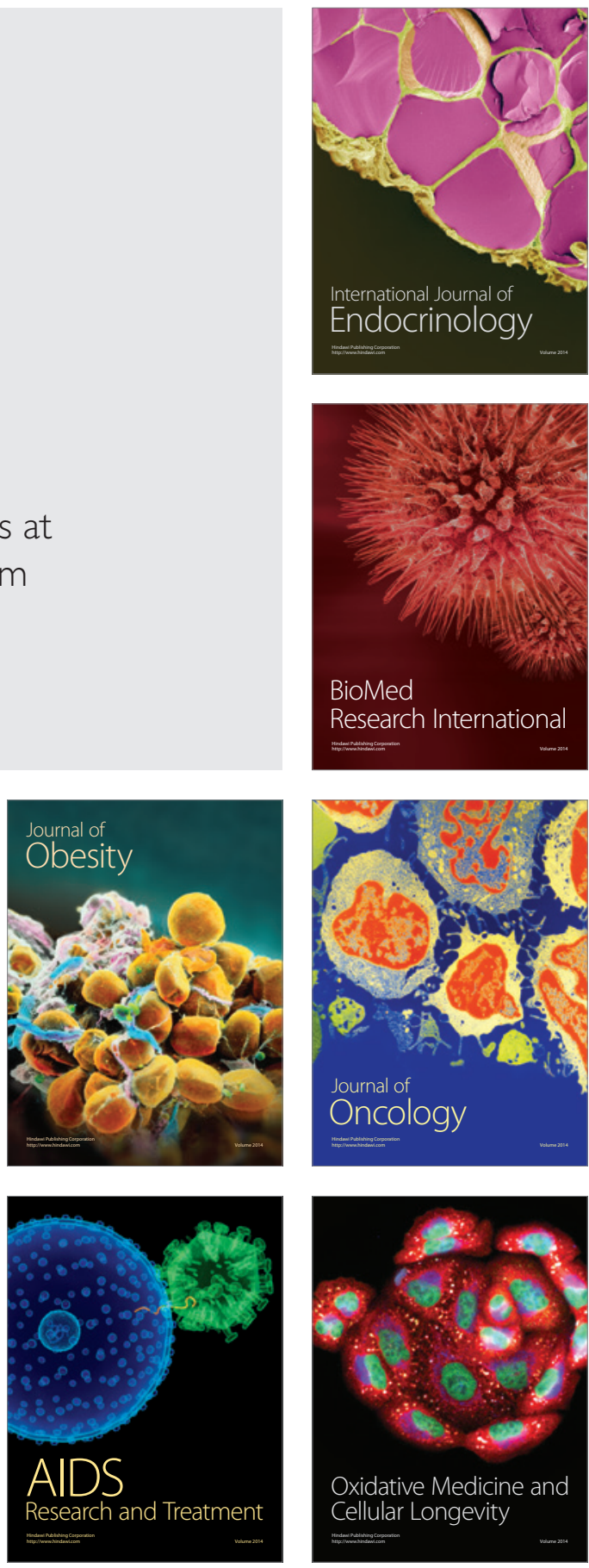